\title{
PSYCHOLOGICA
}

\section{Why be moral? In defense of a Kohlbergian approach}

Autor(es): $\quad$ Lourenço, Orlando; Universidade de Coimbra. Faculdade de Psicologia e de Ciências da Educação (ed. lit.)

Publicado por: Imprensa da Universidade de Coimbra

URL

persistente: URI:http://hdl.handle.net/10316.2/29954

DOI: DOI:http://dx.doi.org/10.14195/1647-8606_56_2

Accessed : $\quad$ 26-Apr-2023 12:16:06

A navegação consulta e descarregamento dos títulos inseridos nas Bibliotecas Digitais UC Digitalis, UC Pombalina e UC Impactum, pressupõem a aceitação plena e sem reservas dos Termos e Condições de Uso destas Bibliotecas Digitais, disponíveis em https://digitalis.uc.pt/pt-pt/termos.

Conforme exposto nos referidos Termos e Condições de Uso, o descarregamento de títulos de acesso restrito requer uma licença válida de autorização devendo o utilizador aceder ao(s) documento(s) a partir de um endereço de IP da instituição detentora da supramencionada licença.

Ao utilizador é apenas permitido o descarregamento para uso pessoal, pelo que o emprego do(s) título(s) descarregado(s) para outro fim, designadamente comercial, carece de autorização do respetivo autor ou editor da obra.

Na medida em que todas as obras da UC Digitalis se encontram protegidas pelo Código do Direito de Autor e Direitos Conexos e demais legislação aplicável, toda a cópia, parcial ou total, deste documento, nos casos em que é legalmente admitida, deverá conter ou fazer-se acompanhar por este aviso. 
VOLUME 2013

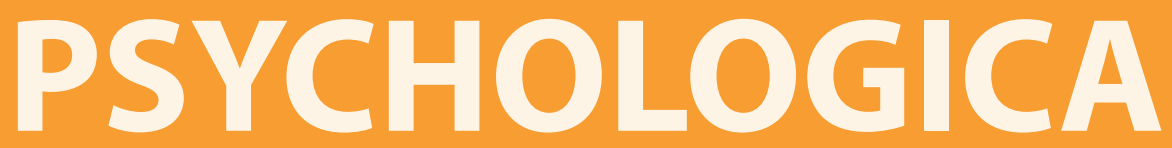

IMPRENSA DA UNIVERSIDADE DE COIMBRA

COIMBRA UNIVERSITY PRESS

FACULDADE DE PSICOLOGIA E DE CIÊNCIAS

DA EDUCAÇÃO DA UNIVERSIDADE DE COIMBRA 


\title{
Why be moral? In defense of a Kohlbergian approach
}

\author{
Orlando Lourenço ${ }^{1}$
}

\begin{abstract}
This article revolves around the "Why be moral?" question, a fundamental ethical question raised by Kohlberg and Ryncarz (1990) in the field of moral development. The study is in three parts. In the first part, Introduction, I refer to this fundamental ethical question and the questions related to it. In the second part, I compare Kohlberg's response to that question and the questions related to it with those given, implicitly or explicitly, by other relevant figures of developmental psychology. Contrary to other developmental psychologists, I argue that, for several reasons, Kohlberg's response to the why be moral question is more complete and deeper than that presented by the relevant developmental figures analyzed in this article. Despite this, I recognize that, as far as the other questions associated with the why be moral question are concerned, all those figures made important contributions to a better understanding of one's moral functioning, and that some of them explored moral issues, which, to some extent, were overlooked by Kohlberg. In the third part, Final Words, I summarize the main ideas of the paper and enumerate several reasons why Kohlberg's answer to the why be moral question is the most complete and deepest one among those presented so far in the field of moral development.
\end{abstract}

Key-words: Morality; development; why be moral; Kohlberg

1 Department of Psychology, University of Lisbon. E-mail: oml2105@fp.ul.pt 


\section{Porquê ser moral? Em defesa de uma abordagem Kohlberguiana}

\section{Resumo}

Este artigo anda em torno da questão “Porquê ser moral?", uma questão ética fundamental levantada por Kohlberg e Ryncarz (1990) no campo do desenvolvimento moral. O artigo consta de três partes. Na primeira parte, Introdução, refiro-me a essa questão ética fundamental e às questões relacionadas com tal questão. Na segunda, comparo a resposta de Kohlberg a todas estas questões com as respostas a tais questões que foram dadas, implícita ou explicitamente, por outras figuras relevantes da psicologia do desenvolvimento. Ao invés de outros psicólogos do desenvolvimento, argumento que, por razões várias, a resposta de Kohlberg à questão por que razão ser moral é mais completa e profunda do que a apresentada pelas figuras relevantes do desenvolvimento analisadas neste artigo. Não obstante este facto, reconheço que, no que concerne às outras questões associadas com a questão do por que razão ser moral, todas essas figuras deixaram contributos para uma melhor compreensão do funcionamento moral da pessoa e que algumas delas exploraram aspectos morais que, em certa extensão, foram subestimados por Kohlberg. Na terceira parte, Palavras Finais, resumo as principais as razões deste artigo e enumero as razões pelas quais a resposta de Kohlberg à questão "Porquê ser moral?" é mais completa e profunda entre as apresentadas até agora no campo do desenvolvimento moral.

Palavras-chave: Moralidade; desenvolvimento moral; por que razão ser moral; Kohlberg.

\section{INTRODUCTION}

The why be moral question has given rise to much theoretical debate and empirical research (e.g., Bergman, 2002, 2004; Blasi, 1999, 2004; Lapsley \& Narvaez, 2004; Narvaez \& Lapsley, 2009). This question in developmental moral psychology was posed cogently by Kohlberg \& Ryncarz in 1990: "Even after attainment of Stage 6's clear awareness of universal principles, a fundamental ethical question still remains, namely, 'Why be moral?'. Why be just in a universe that appears unjust? This question asks whether there is any support in reality or nature for acting according to universal moral principles..." (p. 192). As everyone acquainted with Kohlberg's (e.g., 1981, 1984) theory knows, universal moral principles are reversible principles that should be followed at all times in all moral situations, which reminds us of Kant's (1959) categorical imperative. In other words, principles that, as it were, would pass the reversibility test (e.g., "Would I advocate the same 
solution as that which I defend in a certain moral dilemma if I were in a different position in that dilemma?"), and the universalizability test (e.g., "Would I advocate the same solution as that which I defend in that moral dilemma if it occurred at a different time and place?").

Although the question, Why be moral?, is markedly philosophical (see Levinas, 1982; Ricoeur, 2001, and more in the Final Words section), it can also be seen in psychological terms, even though, to my knowledge, this question has not yet been addressed in empirical terms in the sense posited in the above mentioned Kohlbergian and Ryncarzian quotation.

In a synoptic paper titled "Why be moral? A Conceptual Model from Developmental Psychology", Bergman (2002) elaborates on how relevant figures in developmental psychology, Piaget (1977), Kohlberg (1981, 1984; Kohlberg, Boyd, \& Levine, 1990; Kohlberg \& Candee, 1984), Rest (1984, 1986), Colby and Damon (1992, 1995), and Blasi $(1984,1985,1999,2004)$, have considered the complex relationships among moral reasoning, moral motivation, moral action, and moral identity and, hence, how these figures “... implicitly or explicitly answer the question, Why be moral?" (Bergman, 202, p. 105). Bergman's main conclusion is that, among the theories he analyzes throughout his paper, Blasi's moral identity theory (see below) represents the best approach to the why be moral question, for "... it combines the insights of both Kohlberg, and Colby and Damon." (Bergman, 2002, p. 122). As suggested by the title of this article, I espouse a different view.

In my understanding, the why be moral question raised by Kohlberg (Kohlberg \& Ryncarz, 1990, p, 192) appeals, in different degrees, to the six following issues: 1) to clarify what means to be moral, the what of morality; 2) to identify the several stages of moral development as time goes by, the when of morality; 3) to explain the conditions and causes that lead us to be moral, the proximal why of morality; 4) to understand the varying processes underlying one's moral-decision making, the how of morality; 5) to understand the complex relationships between moral cognition and moral behavior, the consistency/inconsistency problem of morality; and 6) to speculate and investigate about the ultimate reasons why we must act morally in a universe in which the morally sublime coexists with many examples of clear immorality and injustice, the distal or final why of morality.

In what follows, I compare Kohlberg's response to that question and the questions related to it with those presented, directly ou indirectly, by other relevant figures of developmental psychology. In the process, I argue that, contrary claims notwithstanding (e.g., Bergman, 2002), Kohlberg's approach to the why be moral question constitutes a deeper approach than those proposed by other moral researchers, such as Piaget, Rest, Colby and Damon, and Blasi. However, one may think that there are some aspects referred to above that were analyzed more deeply by 
some of these moral researchers than by Kohlberg (e.g., the questions of moral identity and motivation), an issue I will return later. Turiel's (1983) and Nucci's (2004) contribution to our understanding of the why be moral question could also be analyzed here. I do not refer to their respective contributions to that question due to space limits, and for conceptual and methodological reasons whose deep analysis is beyond the scope of this article. Suffice it to say that these two social domain theorists confound prima facie moral judgments or informational knowledge without any personal moral binding with reversible and universalizable moral principles (see Nunner-Winkler \& Sodian, 1988), and employ weak methodologies (see Lourenço, 2003) to demonstrate what they call" ... the sophistication of young children's moral thinking" (Tisak, 1995, p. 96).

\section{KOHLBERG AND PIAGET}

In the Introduction of this paper, I stated that the why be moral question requires a previous answer to what means to be moral. At the beginning of his seminal book, The moral judgment of the child, Piaget (1977) answered this question by saying that all morality consists of a system of rules and, hence, what is important is to study how, with increasing age, the child acquires the respect for these norms and follows them when playing certain games (e.g., the marbles game or le jeu des billes).

In terms of what means to be moral, Kohlberg went far beyond Piaget. It suffices to say that respect for moral norms was seen by Kohlberg only as conventional morality. Post conventional morality is a more advanced morality than the conventional one for it implies respect for fundamental moral principles (e.g., the principle of justice), not only for moral norms (e.g., not to steal). In addition, according to Kohlberg (1971), for an action to be moral, it has to be subjectively moral, to appeal to reasons given by subjects whose moral reasoning is post conventional, and also objectively moral, to represent the content, or course of action, chosen by post-conventional subjects in hypothetical or real-life moral dilemmas (for real-life moral dilemmas, see Gilligan, 1982).

In contrast to Kohlberg (e.g., Kohlberg \& Ryncarz, 1990), the why be moral question was not addressed by Piaget, at least in the deepest sense that such question involves, the ultimate reasons why we should be moral. As referred to above, what interested Piaget most was the conscience children acquire for certain norms and rules (e.g., the marbles game rules), and whether or not they follow them as they play that game. 
However, although Piaget has observed that young children considered marbles game rules unalterable and almost sacred, and yet do not follow them when playing it, the problem of the consistency/inconsistency between one's moral cognition and one's moral action was not a problem for Piaget. This is so mainly because for him moral judgment and understanding lag behind moral behavior. In his words, “[t]hought always lags behind action and cooperation has to be practiced for a very long time before its consequences can be brought fully to light by reflective thought." (Piaget, 1977, p. 64). Contrary to Piaget's position, the consistency/inconsistency problem was a big issue for Kohlberg. As he pointed out, “... if there were no conceptually clear relations of judgment to action, our philosophic definition of moral action would be falsified empirically." (Kohlberg, 1984, p. 515; see also Kohlberg \& Candee, 1984). Empirical studies (e.g., Gerson \& Damon, 1978) have shown that the consistency between moral cognition and moral action tends to increase with one's level of moral development. According to Kohlberg (1984, p. 517), deontic judgments, or judgments of what is right, and responsibility judgments, or judgments to act on what one has judged to be right, are partly responsible for such finding. Thus, these two types of judgment represent significant mediators and motivational factors, between one's stages or structures of moral reasoning and one's moral behavior. As he said, " $[w]$ e have, then, a model in which the relationship of moral stage to (...) moral action is mediated by two intervening judgments, deontic choice [or judgment] and responsibility judgments." (Kohlberg, 1984, p. 518). The finding that the morally more advanced individuals are those who are more likely to convert their deontic judgments into responsibility judgments (e.g., McNamee, 1978) supports Kohlberg's claim about the role of one's moral structures, deontic judgments and responsibility judgments in one's moral action.

Contrary to Kohlberg's interest in cognitive moral motivation (see above), questions of moral motivation play no explicit role in Piaget's theory of morality. Piaget (1977) was most interested in what leads the child to act according to an autonomous morality, a morality guided by cooperation, equality, and mutual respect, or according to a heteronomous morality, a morality appealing to simple obedience, constraint out of fear, and unilateral respect. Whereas heteronomous morality results from asymmetrical, adult-child interactions, autonomous morality arises from symmetrical, child-child interactions. Kohlberg's theory also distinguished these two forms of morality (see Colby \& Kohlberg, 1987a, pp. 315-380). However, because he studied moral development mainly among adolescents and adults, Kohlberg $(1976,1984)$ identified six structural stages of moral reasoning and a meta-reflexive stage 7 (Kohlberg \& Ryncarz, 1990). As we will see, according to Kohlberg, the why be moral question has much to do with his stage 7. 
To sum up, Piaget was not concerned with the why be moral question, and regarding other issues having to do, to some extent, with this question, to elaborate on what means to be moral, for instance, Kohlberg went further than Piaget.

\section{KOHLBERG AND REST}

The why be moral question was also not addressed by James Rest, though his approach to moral development has been greatly influenced by Kohlberg's theory. However, in addition to having developed an instrument to evaluate the individual's level of moral reasoning, his well-known Defining Issues Test or DIT (Rest, 1979), which is different from that developed by Kohlberg and his collaborators (Colby \& Kohlberg, 1987a, b), Rest was mainly interested in the inner processes or components that lead to moral behavior. His four components model (see Rest, 1984; Rest, Narvaez, Bebeau, \& Thoma, 1999) describes one's moral functioning in the following way: First, we interpret a given situation as moral or not moral, component 1 or moral sensitivity; second, we formulate the moral ideal in that situation, component 2 or moral judgment; third, we decide whether or not to pursue the moral ideal or moral judgment previously formulated, component 3 or moral motivation; fourth, we act in order to implement the decision taken before, component 4 or one's character attributes, such as perseverance, firm resolve, and strong will, etc.

Rest considered his four components model regarding the relationship between moral cognition and moral action much different from that presented by Kohlberg (1976, 1984; Kohlberg \& Candee, 1984). Rest disagrees with Kohlberg, mainly because, besides other aspects: 1) "[r]easoning about justice is no more the whole of morality..." (1984, p.32); 2) "moral values are not the only values that people have “(Rest, 1986, p. 13); 3) '...moral behavior is an exceedingly complex phenomenon and no single variable (empathy, prosocial orientation, stages of moral reasoning, etc.) is sufficiently comprehensive to represent the psychology of morality (Rest, 1986, p.18); 4) moral motivation plays no role in Kohlberg's ideas on the moral cognition/moral action question; and 5), at its best, Kohlberg's model of the relationship of moral cognition to moral action, (see above) has only something to say about component 2 as well as component 3 of his four components model. In other words, Rest saw some resemblances between component 2 of his model, to formulate the moral ideal in the situation at hand, and Kohlberg's (1984, p. 517) concept of deontic judgment, “... a judgment of what is right."; and also some similitude between component 3 of his model, to decide whether to pursue that 
moral ideal, and Kohlberg's (1984, p. 517) idea of “... a judgment of responsibility to act on what one has judged to be right."

Confronted with the above mentioned points raised against Kohlberg by Rest, a Kohlbergian oriented developmental psychologist could say that, although justice is for Kohlberg (1971, p. 220) “...the basic moral principle”, for him, too, reasoning about justice is not the whole of morality. As previously seen, moral action, for instance, not only reasoning about justice has a room in Kohlberg's theory. Contrary to Rest's suggestion that moral values are, for Kohlberg, the only values that people have, it suffices to remember that, for him, " $t \mathrm{t}]$ he basic motivation for morality is rooted in a generalized motivation for acceptance, competence, self-esteem, or self-realization.” (Kohlberg, 1987, p. 312). This Kohlberg's quotation also shows that it is simply wrong to say that moral motivation plays no role in Kohlberg's ideas on the relationship of moral cognition to moral action.

(Rest, 1986, p. 18) suggests that, for Kohlberg, moral behavior is not an exceedingly complex phenomenon. Nowhere have I seen that, for Kohlberg, moral behavior is a simple phenomenon, something that can be explained by a single variable. In addition to what was already said regarding Kohlberg's model of the relationship of moral cognition to moral action, one may still add that he explicitly recognized that one can reason in terms of moral principles and not to live in accordance with them and, hence, that there are also multiple situational factors which determine whether, in a given situation, one lives according to one's moral reasoning (see Kohlberg, 1976, p.32). One may still think (see Bergman, 2002, 2004) that Kohlberg's model of the relationship of moral cognition to moral action also involves four components, which make us think of Rest's four processes model: First, moral stage and moral type (i.e., type A or heteronomous type; type B, or autonomous type), component 1 , which leads one to interpret a situation as moral or not moral; Second, deontic judgments, component 2, which lead one to see what action is right or obligatory; third, responsibility judgments, component 3, which lead one to decide to act on what one has judged to be right; fourth, moral action, component 4 , that is, to act according to what one has judged to be right. It is worth mentioning that, for Kohlberg, the move from a decision to act (component 3 ) to the implementation of this decision (component 4) can be influenced by not moral values, chiefly among them the ego strength or strong will. Again, this shows considerable similarity with one's character attributes, such as perseverance, firm resolve, competence, etc., attributes that lie also at the heart of component 4 of Rest's model.

In summary, Rest never addressed the why be moral question in the foundational and philosophical sense that it involves for Kohlberg. With respect to other issues related, to some extent, to this question, to assess one's level of moral development, for instance, Rest's (1979) Defining Issues Test is far from being so deep as is 
Kohlberg's (1987a,b) methodology. In the same vein, Rest's (1984) four components model is not, as he claimed, so different from that presented by Kohlberg (1984; Kohlberg \& Candee, 1984).

\section{KOHLBERG, AND DAMON AND COLBY}

Regarding the study of moral development as well as the why be moral question, Damon (1984) and Colby (Colby \& Damon, 1992, 1993, 1995) see their theory as an alternative to that of Kohlberg. Succinctly, their approach involves three main claims: First," [a] person's level of moral judgment does not determine the person's views on morality's place in one's life. To know how an individual deals with this latter issue, we must know about not only the person's moral beliefs but also the person's understanding of the self in relation to these moral beliefs." (Damon, 1984, p. 110); second, as development goes on, there is an increasing integration between the self and morality, that is, "[o]ne's moral interests and self-interests become more clearly defined and connected to each other..." (Damon, 1984, p.109); Third, this integration is so great in moral exemplars, persons who had been nominated as such by some moral philosophers, theologians, ethicists, historians, and social scientists, because of their contribution to peace, civil rights, religious freedom etc., that none of them "saw their moral choice as an exercise in self-sacrifice." (Colby \& Damon, 1992, p. 303, emphasis in original). In other words, not to act morally would be for these moral exemplars to give up their selves, personalities, or identities. "They performed their moral actions spontaneously, as if they had no choice in the matter." (p. 300). It is worth mentioning that, when they were assessed in their moral reasoning in an abbreviated Kohlbergian moral judgment interview (i.e., the Heinz dilemma), their scores ranged from stage 3 (2 subjects), to stage 5 (4 subjects), with the majority (13 subjects) scoring at 4 or $4 / 5$ stages (Colby \& Damon, 1992, p. 328). There were no stage 6 individuals. In short, Colby and Damon $(1992,1995)$ wanted to challenge Kohlberg's insistence on the centrality of moral reasoning and the idea that Kohlberg's moral stages predict moral behavior.

It is true that moral reasoning plays a central role in Kohlberg's theory of morality. However, instead of being a shortcoming, such as Damon and Colby suggest, Kohlberg's focus on the centrality of moral reasoning is a greatness of his theory. Without knowing the cognitive reasons behind our actions, there are acts appearing to be moral that are immoral ultimately. Cooperation, for instance, is generally presented as a mark of an autonomous and advanced morality (see, for instance, Piaget, 1977). What is moral in an act of cooperation in order to steal 
the goods of a given Institute of Social Solidarity? And, contrary to Colby and Damon's $(1992,1995)$ suggestion, Kohlberg's moral stages per se do not allow to predict one's moral behavior. As already mentioned, deontic judgments, responsibility judgments (Kohlberg, 1984, p. 517), self-esteem, self-realization (Kohlberg, 1987, p. 312), situational factors (Kohlberg, 1976, p. 32), etc., also play a role in the passage from moral cognition to moral action. In terms of moral motivation, an issue that lies at the heart of Damon (1984) and Colby's (Colby \& Damon, 1992) approach, they ignore that moral cognition has also an intrinsic motivational power. It is not mere coincidence that none of the moral exemplars they interviewed were pre-conventional, some scored at stage 5 , and the majority at stage 4 or at stage $4 / 5$ (Colby \& Damon, 1992, p. 328). It remains to be known what scores would be obtained by those moral exemplars if their moral reasoning had been assessed by using a complete, instead of an abbreviated, moral judgment interview (see Colby \& Kohlberg, 1987a, b). In addition to this, Colby and Damon are silent about the moral type (i.e., type A, or heteronomous type, and type B, or autonomous type; Colby \& Kohlberg, 1987, a, pp. 315-380) of their moral exemplars. This distinction would have been important because of Kohlberg's discovery that a "type B person is someone who intuitively (...) perceives the central values and obligations (...), and uses these intuitions to generate a judgment of responsibility or necessity in a dilemma" (Kohlberg \& Candee, 1984, p. 63). This means that a type B individual may act in concert with stages more advanced than his moral stage. Given that in his last method for assessing individuals' moral stage (Colby \& Kohlberg, 1987a, b), Kohlberg abandoned his idea of stage 6 as an empirical reality, it is also surprising that Colby and Damon (1992, p. 328) mention that none of their moral exemplars scored at stage 6. One may still think that Kohlberg's (1987) suggestion that the basic motivation for morality also includes one's "self-realization" (p.312, emphasis added ) reminds us, to an extent, of Damon's (1984) idea that "[s]ome [individuals] consider their morality to be central to their self-identities (...) [while] others consider it to be peripheral." (p. 110).

As far as the why be moral question is concerned, one may think that Colby and Damon's $(1992,1995)$ approach has more to do with what leads one to act morally (i.e., the integration of self and morality) than with the ultimate reason why one ought to be moral in a universe full with examples of injustice. In addition, one may still think that Colby and Damon's $(1992,1995)$ idea that persons act morally to maintain their selves, personalities, or identities, is an idea that may lead to a kind of "ethical egoism" (Nucci, 2004, p. 122; see also Moshman, 2004). In other words, we would be moral, not because of our concerns for others, but because of our concerns with ourselves. In this regard, Damon and Colby are far from Kohlberg's more universal idea that we should treat others as an 
end in themselves, not as a means for our ends, however advanced these ends may be. More to the point, according to Kohlberg, the ultimate reason for one to be moral is related to his meta-reflexive, not structural, stage 7. In Kohlberg's words, "In the state of mind I metaphorically term Stage 7, we identify ourselves with the cosmic or infinite perspective and value life from its standpoint. (...). If we are aware of the relationship of all people and things to the whole of Nature, then we continue to love the whole in spite of the disappointments or losses." (Kohlberg \& Ryncarz, 1990, pp. 192-196). To put it simply, according to Damon (1984) and Colby (Colby \& Damon, 1992, 1995), we are moral to live in harmony with our selves, personalities, and identities. For Kohlberg (Kohlberg \& Ryncarz, 1990), we should be moral, not only for living in harmony with ourselves, but for living in harmony with the whole of Nature, in harmony, that is, with ourselves, with all people and even with all things. One may object that this Kohlberg's answer to the why be moral question is more philosophical than psychological. Although true, such an objection misses the point for it forgets that the why be moral question, as well as the why live question, is from its very beginning more philosophical than psychological. Kohlberg's position has the advantage of elaborating on both aspects.

To sum up, with their idea of the unity between self and morality as an answer to the why be moral question, Colby and Damon $(1992,1995)$ brought to light the importance of non cognitive motivations for one to be moral, an aspect that Kohlberg's theory overlooks. In spite of this, Kohlberg's answer to such question seems to me to be deeper than that offered by Colby and Damon. First, as seen before, non cognitive motivational dimensions for one to be moral also play a role in Kohlberg's theory; second, compared to Kohlberg's views, Damon and Colby almost ignore the role of moral reasoning in their approach to morality. Given that moral reasoning is a requisite for an action to be judged moral or immoral, any approach to the why be moral question that ignores such requisite partly loses its raison d'être. Finally, and more important, Kohlberg's approach to the why be moral question addresses philosophical issues totally ignored by Damon and Colby's theory. Needless to say, even the question of what means to be moral already lifts up philosophical aspects, as is easily visible in the different ways how moral psychologists and moral philosophers consider an action to be moral or just. For example, for Kohlberg (1984), to be moral is not to treat others unfairly or to follow the principle of justice; For Gilligan (1982), is not to abandon others in need or to follow the principle of benevolence. For Bentham (1983), is to assure the greatest happiness of the greatest number or to follow the principle of utilitarianism; and for Den Wyl (1991), is to follow the Aristotlian principle of eudaimonia (a Greek word), or to pursue our self-fulfillment and happiness. 


\section{KOHLBERG AND BLASI}

Blasi (1984, 1990, 1995, 2004), like Rest, and Damon and Colby, did not feel totally satisfied with Kohlberg's theory regarding the passage from moral cognition to moral action, and hence, with his approach to the why be moral question. As he pointed out: "We need a psychological theory to explain how and why moral understanding leads, when it does, to the desire to act morally."(Blasi, 1990, p. 53).

At the heart of Blasi's theory, known as self model (Blasi, 1983) or moral identity (1984), lie mainly the four following theses: first, " $\mathrm{t}$ ] he transition from a judgment of responsibility to action is supported dynamically by the tendency toward consistency, a central tendency in personality organization." (Blasi, 1983, p. 201); second, "not to act according to one's judgment should be perceived as a substantial inconsistency, as a fracture within the very core of the self ..." (Blasi, 1983 , p. 201, emphasis added); third, “... morality and identity or the self-concept are separate psychological systems which only slowly, and sometimes imperfectly, come together and become integrated." (Blasi, 1995, p. 229). To justify this third thesis, Blasi $(1989,1995)$ tends to appeal to two types of data. One type has to do with a Blasi's research on the degree of personal integration of moral responsibility among three groups of children with average ages of 6,12, and 17. Results have shown that "... the sense of personal obligation is largely absent among 6-yearolds, but it is well understood by the large majority of 12 -year-olds (...). In many 17-year-olds the sense of obligation is tied to personally held beliefs and the sense of personal integrity." (Blasi, 1989, p. 126, emphasis added). The other type of data has to do with research on the happy victimizer phenomenon (e.g., Doherty, 2008; Keller, Lourenço, Malti, \& Saalback, 2003; Nunner-Winkler \& Sodian, 1988), which shows that even though children younger than 8-9-year-olds tend to judge certain moral transgressions (e.g., stealing) to be wrong, they end up by attributing positive emotions, to feel good, for instance, to the transgressor. In Blasi's (1989) words, this result reveals that "...moral understanding appears to be possible without it being integrated with the appropriate emotions and motives.” (p. 125). Finally, “... moral understanding eventually acquires its own motivational power, one, namely, that is intrinsic in the nature itself of morality...”. (Blasi, 1995, p. 237, emphasis in original).

Because of what I said so far, it is easily visible that the first three theses of Blasi's approach (i.e., we are moral to maintain our consistency; to maintain our identity; when it occurs, the integration of morality and identity is a developmental process) are similar to those of Colby and Damon $(1992,1995)$, namely, to their idea that one acts morally when there is an integration of self and morality, and relatively inconsistent with Kohlberg's ideas regarding the passage from moral cognition to 
moral action. If these first three theses of Blasi's approach are somehow inconsistent with Kohlberg's ideas concerning the passage from moral cognition to moral action, the fourth thesis of Blasi's approach (i.e., moral understanding has its own motivational power) is based on Kohlberg's $(1971,1984)$ thinking, and plays no role in Colby and Damon's $(1992,1993,1995)$ approach. The influence of Kohlberg's theory on Blasi's thinking is also visible in his idea that the importance of self or identity to moral motivation does not imply to downplay the role of moral judgment. In his words: “... the self's very identity is constructed, at least in part, under the influence of moral reasons...”. (Blasi, 1984, p. 138, emphasis added). This means that, contrary to Colby and Damon's approach, Blasi's theory of moral identity preserves the centrality of moral judgment in moral action and development. In other words, compared to the theories already presented, Blasi's approach combines the insights of both Kohlberg, and Colby and Damon.

It is true that, with his theory of moral identity, theory according to which one would lose his or her identity if he or she did not act morally, Blasi (1983, 1984, $1995,2004)$ brought to light the importance of non-cognitive motivational dimensions to explain why we act morally. However, it should be noted that Kohlberg's (1987, p. 312) idea that self-esteem, or self-realization are motivations for moral action reminds us, to some extent, of the first two theses of Blasi's approach (i.e., we act morally to be self-consistent and preserve our identity). Similarly, Blasi's idea that the sense of moral obligation increases with age is also a Kohlbergian thesis. Actually, at pre-conventional stages there is only a sense of pseudo moral obligation. In its deepest meaning, moral obligation appears only at post conventional stages. According to some others (e.g., Lourenço, 2003), post conventional stages make us think of "necessary" moral knowledge, a type of knowledge which leads us to act morally, as if an internal moral compulsion were the case. It is this moral obligation or "necessary" moral knowledge that, I believe, lies at the heart of Kohlberg's (1971, p. 232) thesis that “... who knows the good chooses the good." Because of these reasons, it seems to me to be a bit exaggerated Blasi's claim that "[w]e need a psychological theory to explain how and why moral understanding leads, when it does, to the desire to act morally." (Blasi, 1990, p. 53).

Regarding the answer to the why be moral question, I think that Blasi went further than Rest, Damon and Colby, but not so far as Kohlberg. Rest, Damon and Colby were mainly interested in identifying the inner processes and dimensions which lead us to be moral in challenging situations. In addition to these aspects, Blasi (1984. p. 438) was also interested in the more fundamental question, "What kind of person should one, or must one, be?, a question he distinguishes from the question,"What kind of person I want to be?” (see Bergman, 2004, p. 35). As already mentioned, Blasi answers that we should be moral for not opening “... a fracture 
within the very core of the self ..." (Blasi, 1983, p. 201, emphasis added), an answer which, like that given by Colby and Damon, may lead us to think of a certain ethical egoism (see Nucci, 2004). As referred to earlier, Kohlberg's answer to the why be moral question is more philosophical, foundational, and comprehensive. We ought to be moral for not opening a fracture within the cosmos or the whole of nature. As he said, “...[I]n the state of mind I metaphorically term Stage 7, we identify ourselves with the cosmic or infinitive perspective (...). If we are aware of the relationship of all people and things to the whole of Nature, then we continue to love the whole...". (Kohlberg \& Ryncarz, 1990, pp. 192-196, emphasis added). The fact that Kohlberg uses here the term to love the whole seems to mean that, for him, contrary claims notwithstanding (e.g., Colby \& Damon, 1992, 1995), to be moral implies heart and reason, not only reason.

To sum up, with his theory of moral identity, Blasi enhanced our understanding of Damon and Colby's (1992) idea that the unity of self and morality plays an important role in moral motivation and action. However, contrary to such Damon and Colby's idea, Blasi's (2004) theory does not downplay the role of moral judgment, which renders his theory consistent with a central tenet of Kohlberg's approach. In this vein, it is worth mentioning that the role of reason in one's moral judgments and decisions, which is central in Piaget's (1977), and Kohlberg's (1984) moral theories, is now being dismissed by a reductionist and anti-rationalist tendency in many fields of psychology whose whole description, strengths, and shortcomings is beyond the scope of this article. For example, according to Haidt's (2001) social intuitionist model, we first form our moral judgments and decisions with basis on intuitions and emotions and then give reasons for them, our reasons serving as ex-post facto rationalizations to convince ourselves/others that our moral judgments and decisions are a reason-based process. As previously argued, to ignore or even overlook the role of moral reasoning in any moral theory amounts to not having any moral theory at all (see Kasachkoff \& Saltzstein, 2006). It suffices to say that moral reasons are part and parcel of the definition of the moral action itself.

Concerning the why be moral question, Blasi, as we have just shown, treated it mainly in the sense of viewing what leads one to act morally. In addition to taking into account this aspect, Kohlberg, by relating the why be moral question to the why live question, a question which is more philosophical than psychological, went farther than Blasi. 


\section{FINAL WORDS}

In this article, I have analyzed, in a summary way, the contribution of Piaget (1977), Rest (1983, 1984), Colby and Damon (1992, 1995), and Blasi (1983, 1984, 2004) to our understanding of the fundamental ethical question: Why be moral? Such analysis was made by comparing the contribution of each of these authors to that of Kohlberg (1981, 1984, 1987; Kohlberg \& Candee, 1984; Kohlberg \& Ryncarz, 1990). In the process, I also elaborated on other issues having to do with this fundamental question, namely, what means to be moral; what leads one to act morally in challenging moral situations; what processes underlie one's moral-decision making; and what are the complex relationships of moral cognition to moral action.

To sum up, Piaget (1977) did not address the why be moral question in the deep sense that Kohlberg raised it. He was, however, one of the first developmental psychologists to give a definition of what means to be moral. In contrast to the other authors on whom I elaborated, for Piaget the problem was not to explain the passage from moral cognition to moral action, but the passage from moral action to moral cognition.

Rest (1983, 1984; Rest et al., 1999) did not address either the why be moral question in its deepest sense. He was mainly interested in identifying the inner processes underlying the passage from one's moral cognition to one's moral action, having then formulating his four components model.

Non cognitive moral motivations play a substantial role in Damon and Colby's theory (Colby \& Damon, 1992, 1993, 1995; Damon, 1984). According to Colby and Damon, we act morally when morality becomes a dominant characteristic of the self, this being particularly notorious in the moral exemplars they interviewed. This answer, however, shows that for them the why be moral question is more a question about what leads one to act morally than a question about why we should be moral. This means that Colby and Damon did not elaborate on the why be moral question in its deepest meaning.

The role of moral motivation in the passage from moral cognition to moral action is also stressed in Blasi's $(1983,1984,2004)$ moral identity theory. According to Blasi, we act morally to preserve our identity and, hence, not to betray the self. This Blasi's answer shows that, in spite of his distinction between the question, What kind of person must one be?, and the question, What kind of person I want to be?", he addressed mainly the latter, not the former. In this respect, it is telling that, when Blasi (1990, p. 53) mentions that we need a theory to explain how and why moral judgment leads, when it does, to moral action, he refers to a desire, not to an obligation. This means that the why be moral question in its deepest and philosophical sense was not addressed either by Blasi. To answer to the why be 
moral question by appealing to a desire, not to an obligation, raises the following more than legitimate problem: Am I not obliged to be moral if I do not desire to act morally? In short, Kohlberg's question, Why be moral?, was transformed by Blasi into the question, "Why I want be moral?.

As suggested throughout this article, I think that Kohlberg's (1981, 1984; Kohlberg, Boyd, \& Levine, 1990; Kohlberg \& Candee, 1984) theory constitutes the deepest approach to the fundamental ethical question, Why be moral?. Among others, for the five following reasons: 1) It was Kohlberg who first raised such question in moral developmental psychology; 2) it was him who presented a more demanding idea of what means to be moral; 3) his approach deals with all aspects eventually related to such question, namely, what leads one to be moral, what processes are involved in the passage from moral cognition to moral action, what leads one to act, or not to act, on one's moral judgments. Finally, and more important, it was Kohlberg who gave the more profound answer to that question, for his response involves not only psychological, but also philosophical, aspects. That is, his answer to such question points to the more likely variables which lead us to be moral, but also to the reasons why we are obliged to be moral. Damon, Colby and Blasi defend that we are moral in order to not introduce a fracture within the very core of the self, and maintain our integrity and identity. Kohlberg answers that we should be moral to maintain the unity of the whole and ourselves or to identify ourselves with a cosmic or infinite perspective. As he has proclaimed: "If we are aware of the relationship of all people and things to the whole of Nature, then we continue to love the whole in spite of disappointments or losses." (Kohlberg \& Ryncarz, 1990, p. 196). This means that Kohlberg's response to the why be moral question contains a spiritual, not necessarily religious, dimension, which is not visible in any theory I succinctly analyzed throughout this article. This spiritual albeit not religious dimension is visible in the natural law perspective to which appeals Kohlberg's stage 7. As he put it, “[s]tage 7's natural law perspective stands in sharp contrast to [both the] divine command theory...[and the] emotivist theory. The first ... is a fundamentalist theory that states that morality is ultimately defined or rests upon divine command as revealed by the Bible or other documents of revelation. The second...states that morality is in part and religion is altogether an 'illusion' born of irrational human fantasy and conflict”' (Kohlberg \& Ryncarz, 1990, p. 196). This is the reason why Kohlberg's moral theory and his answer to the why be moral questions is secular rather than religious. As a result, we all are obliged to be moral, regardless of our religious believes or our emotional conflicts and fantasies.

Of course, it would be interesting to discuss the "Why be moral?" question itself. I mean to deconstruct it and try to rephrase it in different ways to assess 
whether it couldn't have a "bigger heuristic value" or moral interest if reconstructed in such or such a way. For example, both Ricoeur (2001) and Levinas (1982) gave an anthropologic origin to the moral behaviour and reasoning. Ricoeur named this fundamental human characteristic: the ethical intention (in French: la visée éthique). He defined this intention, notably, as the care for distant others, for fair institutions and for a good personal life. Levinas went even further in this direction when he related this intention with an absolutely primordial formative experience, which he called: "the face" (in French: le "visage"). As far as I know, these two thinkers and ideas have not yet been explored empirically by psychologists in spite of their heuristic value for our understanding of the "Why be moral question?" The same could be said, for instance, about the Canadian philosopher Charles Taylor's (1989) thesis that the self can exist only within a moral space, and the German philosopher Hans Jonas' (1984) idea of his imperative of responsibility. I think that these important thinkers and ideas will have a major impact on the psychologists' theoretical debate and empirical research.

Needless to say that the present article followed a different track, namely to show and argue that, compared to other developmental psychologists, it was Kohlberg who addresses the fundamental ethical questions, Why be moral?, in a deepest way.

\section{REFERENCES}

Bentham, J. (1983). Deontology. In J. Dinwiddy (Ed.), The collected works of Jeremy Bentham: Deontology together with a table of springs of action and the article on utilitarianism. Oxford: Clarendon Press. (Original work published 1834)

Bergman, R. (2002). Why be moral? A conceptual model from developmental psychology. Human Development, 45, 104-124.

Bergman, R. (2004). Identity as motivation: Toward a theory of the moral self. In D. Lapsley \& D. Narvaez (Eds.), Moral development, self, and identity (pp. 21-46). Mahawh, NJ: Erlbaum.

Blasi, A. (1983). Moral cognition and moral action: A theoretical perspective. Developmental Review, 3, 178-210.

Blasi, A. (1984). Moral identity: Its role in moral functioning. In W. Kurtinez \& J. Gewirtz (Eds.), Morality, moral behavior, and moral development (pp. 128-139). NewYork: Wiley.

Blasi, A. (1985). The moral personality: Reflections for social science and education. In M. Berkowitz \& F. Oser (Eds.), Moral education: Theory and application (pp. 433-444). Hillsdale, NJ: Erlbaum.

Blasi, A. (1989). The integration of morality in personality. In I. Bilbao (Ed.), Perspectivas acerca de cambio moral: Posibles intervenciones educativas [perspectives on moral change: Possible educational interventions ] (pp. 121-131). San Sebastian, Spain: Servicio Editorial Universidad Del Pais Basco.

Blasi, A. (1990). Kohlberg's theory and moral motivation. New Directions for Child Development, 47, 51-57. 
Blasi, A. (1995). Moral understanding and the moral personality: The process of moral integration. In W. Kurtinez \& J. Gewirtz (Eds.), Moral development: An introduction (pp. 229-253). Boston, MA: Allyn and Bacon.

Blasi, A. (1999). Emotions and moral motivation. Journal for the Theory of Social Behaviour, 29, 1-19. Blasi, A. (2004). Moral functioning: Moral understanding and personality In D. Lapsley \& D. Narvaez (Eds.), Moral development, self, and identity (pp. 335-347). Mahawh, NJ: Erlbaum.

Colby, A., \& Damon. W. (1992). Some do care: Conceptual lives of moral commitment. New York: The Free Press.

Colby, A., \& Damon, W. (1993). The uniting of self and morality in the development of extraordinary moral commitment. In G. Noam \& T. Wren (Eds.), The moral domain (pp. 149-174). Cambridge, MA: MIT Press.

Colby, A., \& Damon, W. (1995). The development of extraordinary moral commitment. In M. Killen \& D. Hart (Eds.), Morality in everyday life: Developmental perspectives (pp. 342-370). New York: Cambridge University Press.

Colby, A., \& Kohlberg, L. (1987a). The measurement of moral judgment. Vol.1: Theoretical foundations and research validation. Cambridge: Cambridge University Press.

Colby, A., \& Kohlberg, L. (1987b). The measurement of moral judgment. Vol.2: Standard issue scoring manual. Cambridge: Cambridge University Press.

Damon, W. (1984). Self-understanding and moral development from childhood to adolescence. In W. Kurtinez \& J. Gewirtz (Eds.), Morality, moral behavior, and moral development (pp. 109-127). NewYork: Wiley.

Den Wyl, D. (1991). The virtue of prudence. New York: Peter Lang.

Doherty, M. (2008). Theory of mind: How children understand others' thoughts and feelings. Howe: Psychology Press.

Gerson, R., \& Damon, W. (1978). Moral understanding and children's conduct. In W. Damon (Ed.), New directions for child development: Moral development (pp. 41-49). San Francisco: Jossey-Bass.

Gilligan, C. (1982). In a different voice: Psychological theory and women's development. Cambridge MA: Harvard University Press.

Haidt, J. (2001). The emotional dog and its rational tail: A social intuitionist approach to morality. Psychological Review, 108, 814-834.

Jonas, H. (1984). The imperative of responsibility: In search of responsibility of ethics for the technological age. Chicago: Chicago University Press.

Kant, I. (1959). Foundations of the metaphysics of morals (L. Beck, Trans.). Indianapolis: Bobbs-Merrill. (Original work published 1785)

Kasachkoff, T., \& Saltzstein, H. (2006). Reasoning and moral decision-making: A critique of the social intuitionist model. European Journal of Developmental Science, 2, 287-302.

Keller, M., Lourenço, O., Malti, T., \& Saalbach, H. (2003). The multifaceted phenomenon of 'happy victimizers': A cross-cultural comparison of moral emotions. British Journal of Developmental Psychology, 21, 1-18.

Kohlberg, L. (1971). From is to ought: How to commit the naturalistic fallacy and get away with it in the study of moral development. In T. Mischel (Ed.), Cognitive development and epistemology (pp. 151-235). New York: Academic Press.

Kohlberg, L. (1976). Moral stages and moralization. The cognitive developmental approach. In T. Lickona (Ed.), Moral development and behavior (pp. 31-53). New York: Holt, Rinehart and Winston.

Kohlberg, L. (1981). Essays on moral development. Vol 1: The philosophy of moral development. New York: Haper \& Row. 
Kohlberg, L. (1984). Essays on moral development. Vol 2: The psychology of moral Development: Moral stages, their nature and validation. New York: Haper \& Row.

Kohlberg, L. (1987). The development of moral judgment and moral action. In L. Kohlberg (Ed.), Child psychology and childhood education: A cognitive developmental view (pp. 259-328). New York: Longman.

Kohlberg, L., Boyd, D., \& Levine, C. (1990). The return of stage 6: Its principle and moral point of view. In T. Wren (Ed.), The moral domain (pp. 151-181). Cambridge: The MIT Press.

Kohlberg, L., \& Candee, D. (1984). The relationship of moral judgment to moral action. In W. Kurtinez \& J. Gewirtz (Eds.), Morality, moral behavior, and moral development (pp. 52-73). NewYork: Wiley.

Kohlberg, L., \& Ryncarz, R. (1990). Beyond justice reasoning: moral development and consideration of a seventh stage. In C. Alexander \& A. Langer (Eds.), Higher stages of human development (pp. 191-207): New York: Oxford University Press.

Levinas, E. (1982). Ethique et infini. Dialogues avec Philippe Nemo.[Ethic and the infinite: A conversation with Philippe Nemo]. Paris: Librairie Arthème Fayard et Radio France.

Lourenço, O. (2003). Making sense of Turiel's dispute with Kohlberg: The case of the child's moral competence. New Ideas in Psychology, 21, 43-68.

McNamee, S. (1978). Moral behavior, moral development and motivation. Journal of Moral Education, 7, 27-32.

Moshman, D. (2004). False moral identity: Self-serving denial in the maintenance of moral selfconceptions. In D. Lapsley \& D. Narvaez (Eds.), Moral development, self, and identity (pp. 83-109). Mahawh, NJ: Erlbaum.

Narvaez, D., \& Lapsley, D. (2009) (Eds.), Moral Personality, identity and character: An Interdisciplinary future. New York: Cambridge University Press.

Nucci, L. (2004). Reflections of the moral self construct. In D. Lapsley \& D. Narvaez (Eds.), Moral development, self, and identity (pp. 111-132). Mahawh, NJ: Erlbaum.

Nunner-Winkler, G., \& Sodian, B. (1988). Children's understanding of moral emotions. Child Development, 59, 1323-1338.

Piaget, J. (1977). The moral judgment of the child. New York: Free Press. (Original work published 1932)

Rest, J. (1979). Developing in judging moral issues. Minneapolis, MN: University of Minnesota Press.

Rest, J. (1983). Morality. In P. Mussen (Series Ed.), Handbook of child psychology. Vol 3: Cognitive development (pp. 556-629). New York: Wiley.

Rest, J. (1984). The major components of morality. In W. Kurtinez \& J. Gewirtz (Eds.), Morality, moral behavior, and moral development (pp. 24-40). NewYork: Wiley.

Rest, J. (1986). Moral development: Advances in research and theory. New York: Praeger.

Rest, J., Narvaez, D., Bebeau, M., \& Thoma, S. (1999). Postconventional moral thinking: A neo-Kohlbergian approach. Mahwah, NJ: Erlbaum.

Ricoeur, P. (2001). Le juste. 2. [The just, 2]. Paris : Éditions de Paris.

Taylor, C. (1989). Sources of the self: The making of modern identity. Cambridge MA: Harvard University Press.

Tisak, M. (1995). Domains of social reasoning and beyond. In R.Vasta (Ed.), Annals of child development (Vol. 11, pp. 95-130). London: Jessica Kingsley.

Turiel, E. (1983). The development of social knowledge: Morality and convention. Cambridge: Cambridge University Press 